Article

\title{
Resonance Raman Optical Activity Spectroscopy in Probing Structural Changes Invisible to Circular Dichroism Spectroscopy: A Study on Truncated Vitamin $B_{12}$ Derivatives
}

\author{
Ewa Machalska ${ }^{1,2} \mathbb{D}$, Grzegorz Zajac ${ }^{2}$, Monika Halat ${ }^{1,2}$, Aleksandra J. Wierzba ${ }^{3}$, \\ Dorota Gryko $^{3, *(\mathbb{D})}$ and Malgorzata Baranska ${ }^{1,2, *(\mathbb{D})}$ \\ 1 Faculty of Chemistry, Jagiellonian University, Gronostajowa 2, 30-387 Krakow, Poland; \\ ewa.machalska@doctoral.uj.edu.pl (E.M.); monika.halat@doctoral.uj.edu.pl (M.H.) \\ 2 Jagiellonian Centre for Experimental Therapeutics (JCET), Jagiellonian University, Bobrzynskiego 14, \\ 30-348 Krakow, Poland; zajac@chemia.uj.edu.pl \\ 3 Institute of Organic Chemistry, Polish Academy of Sciences, Kasprzaka 44/52, 01-224 Warsaw, Poland; \\ aleksandra.wierzba@icho.edu.pl \\ * Correspondence: dorota.gryko@icho.edu.pl (D.G.); m.baranska@uj.edu.pl (M.B.); \\ Tel.: +48-22-343-2051 (D.G.); +48-12-686-2389 (M.B.)
}

Academic Editor: Giuliano Siligardi

Received: 31 August 2020; Accepted: 23 September 2020; Published: 24 September 2020

\begin{abstract}
This work demonstrates resonance Raman optical activity (RROA) spectra of three truncated vitamin $B_{12}$ derivatives modified within the nucleotide loop. Since truncated cobalamins possess sufficiently high rotational strength in the range of ROA excitation $(532 \mathrm{~nm})$, it was possible to record their spectra in the resonance condition. They showed several distinct spectral features allowing for the distinguishing of studied compounds, in contrast to other methods, i.e., UV-Vis absorption, electronic circular dichroism, and resonance Raman spectroscopy. The improved capacity of the RROA method is based here on the excitation of molecules via more than two electronic states, giving rise to the bisignate RROA spectrum, significantly distinct from a parent Raman spectrum. This observation is an important step in the dissemination of using RROA spectroscopy in studying the complex structure of corrinoids which may prove crucial for a better understanding of their biological role.
\end{abstract}

Keywords: vitamin $\mathrm{B}_{12}$; cobinamide; chirality; resonance ROA; resonance Raman spectroscopy; ECD

\section{Introduction}

Natural cobalt-corrinoids and their synthetic analogs have recently been widely explored as transporters of biologically important molecules into eukaryotic or prokaryotic cells [1,2], fluorophore probes [3], antivitamins [4,5], and a catalyst [6] like other commonly known catalytic materials [7]. Vitamin $\mathrm{B}_{12}$ (cyanocobalamin, $(\mathrm{CN}) \mathrm{Cbl}$ ), belonging to the best studied among all corrinoid molecules, is a micronutrient isolated from specific bacterial sources e.g., Propionibacteria and Pseudomonas denitnpcans [8,9]. This coordination complex (Figure 1) comprises several relevant structural entities: (1) chiral tetrapyrrolic corrin ring with the central cobalt ion in +3 oxidation state; (2) the nucleotide loop composed of the phosphate group, ribose unit, and 5,6-dimethylbenzimidazole base (Dmb), coordinated to the cobalt atom in the lower axial position $\left(\mathrm{L}_{\alpha}\right)$; (3) $\mathrm{CN}^{-}$group as an upper ligand $\left(\mathrm{L}_{\beta}\right)$. Vitamin $\mathrm{B}_{12}$ seems to have no physiological function in human metabolism [10], nevertheless, organometallic cobalamin cofactors: adenosylcobalamin (AdoCbl) and methylcobalamin (MeCbl) show an enzymatic capacity $[11,12]$. AdoCbl is used for initiating the radical-induced rearrangement 
of substrates [13] or the reduction of ribonucleotides [14], while MeCbl participates in the transfer of the methyl cation [15].
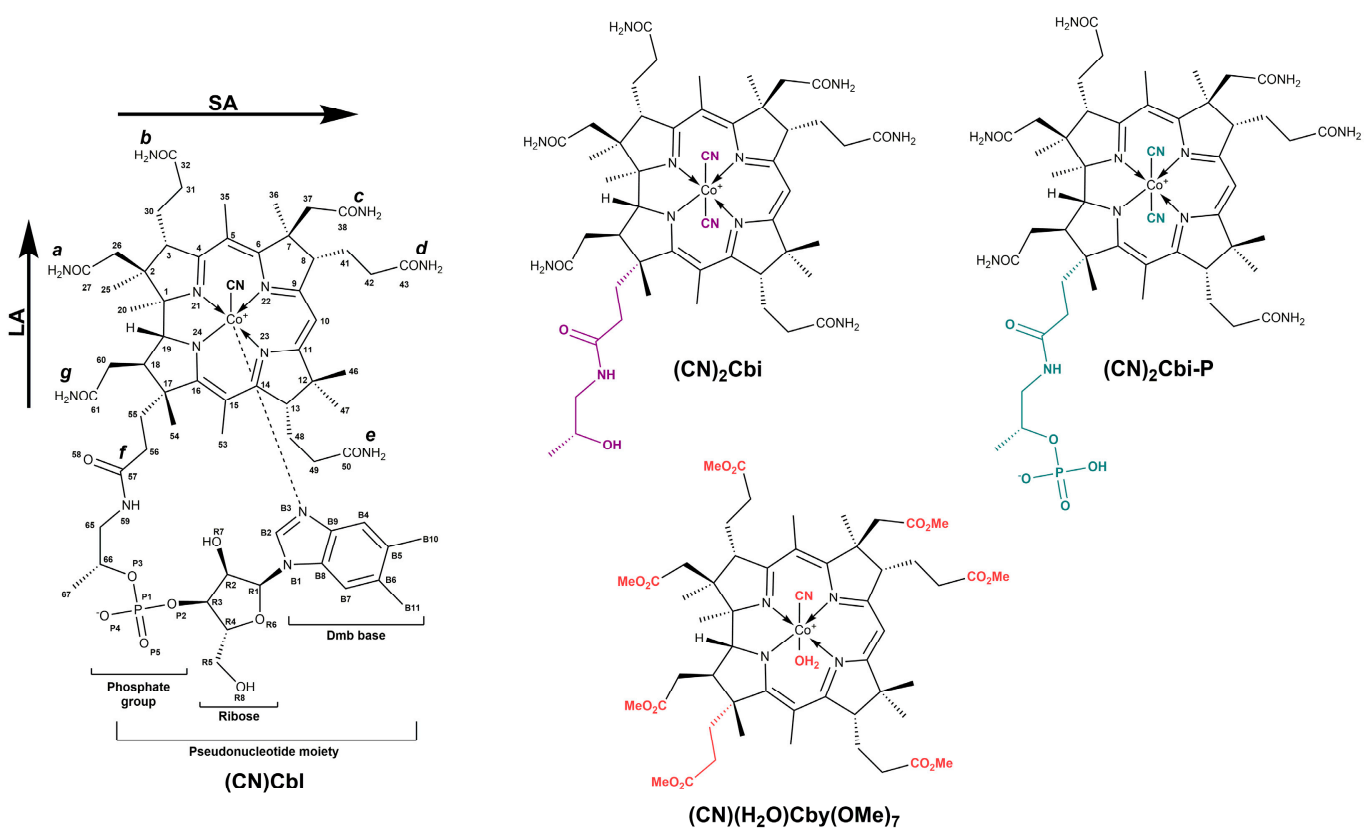

Figure 1. Molecular structure of vitamin $B_{12}$ and its truncated analogs: dicyanocobinamide $\left((\mathrm{CN})_{2} \mathrm{Cbi}\right)$ and its phosphate derivative $\left((\mathrm{CN})_{2} \mathrm{Cbi}-\mathrm{P}\right)$, and cyanoaqua cobyrinic acid heptamethylester $\left((\mathrm{CN})\left(\mathrm{H}_{2} \mathrm{O}\right) \mathrm{Cby}(\mathrm{OMe})_{7}\right)$.

Important representatives of the corrinoid family are truncated vitamin $\mathrm{B}_{12}$ derivatives such as cobyric acid (Cby) and cobinamide (Cbi), obtained via hydrolysis of native cobalamin (Figure 1) [16,17]. The molecular structure of both compounds, $\mathrm{Cby}$ and $\mathrm{Cbi}$, is not as complex as the one of vitamin $\mathrm{B}_{12}$, due to modifications within the $a-f$ side chains or cleavage of the phosphodiester linkage, respectively [18]. The absence of the $\mathrm{Dmb}$ base in the $\alpha$-position of these species not only contributes to richer coordination possibilities, but ensures that aqua $\mathrm{Cbi}$ is a more sensitive probe for cyanide poisoning and its detection, than other generally known antidotes, including sodium nitrite, sodium thiosulfate, and hydroxocobalamin $(\mathrm{OHCbl})[19,20]$. It was noted that Cbi species bind cyanide with high affinity $\left(K_{a} \approx 10^{22} \mathrm{M}^{-1}\right)$, which leads to 2-3 times greater detoxification efficiency, compared to that of cobalamins [21]. The role of $\mathrm{Cbi}$ is not restricted to cyanide neutralization, it is also used to study the function of the lower axial ligand in base-off/His-on cobalamin-dependent enzymes e.g., methylmalonyl-CoA mutase [22].

Until now, vitamin $B_{12}$ and its derivatives have been extensively investigated by means of various methods including electronic absorption (UV-Vis) [23-26] as well as Raman spectroscopy techniques [27-32]. These methods supported by a theoretical approach guarantee insight into the complex nature and electronic or vibrational properties of corrinoids. As it turned out, there is a range of factors influencing the electronic character of the corrin chromophore e.g., (1) type of the central metal ion [33,34]; (2) type of axial ligands attached to the metal ion [35-37]; (3) oxidation state of the cobalt center $[27,38]$; $(4)$ character of substituents attached to the corrin ring or presence/absence of the nucleotide loop [18,39]. Also, electronic circular dichroism spectroscopy (ECD) has proven to be a sensitive method for the detection of a substitution at the central cobalt ion or functionalization of the corrinoid ring [37,40]. However, given the character of the ECD method, arising from the presence of a few intense, but broad, signatures in the chiroptical spectra, this technique yields limited information about the molecular structure. 
We have previously shown that for variously modified cobalamin species, resonance Raman optical activity (RROA) spectroscopy is a method of enhanced structural sensitivity compared to other techniques, including resonance Raman (RR) spectroscopy, and at the same time preserves improved sensitivity as related to the ROA effect itself [41]. According to the single electronic state (SES) limit theory, the RROA spectrum is monosignate with a sign opposite to the ECD signal of the single resonant electronic state. Furthermore, the RROA/RR CID ratio of corresponding bands equals $-g / 2$, where the $g$-factor or dissymmetry factor is the ECD/UV-Vis ratio of the resonant electronic state. Excitation via a single electronic state results in the high similarity of an RROA spectrum to an RR spectrum (corresponding signals have the same intensities, apart from the sign) [42]. On the other hand, the excitation via more than one electronic state, described by two electronic states (TES) [43] or multiple electronic states [44] limit theory, may give rise to a bisignate RROA spectrum. This effect is significantly distinct from the Raman spectrum of a studied molecule and does not obey the $\mathrm{CID}=-g / 2$ rule. The bisignated RROA spectrum may also result from conformational freedom of the molecule $[45,46]$, or weak enhancement, and the presence of non-resonance bands together with the resonantly increased ones [47], and resonance with more than two electronic states [44]. In respect to vitamin $B_{12}$, the bisignate RROA spectra result from the excitation (532 nm) involving at least three closely-lying electronic states, which agrees with the theoretical analysis of their ECD spectra [40].

In this work, we demonstrate the experimental RROA spectra for three vitamin $\mathrm{B}_{12}$ mimics, with a modified nucleotide loop: dicyanocobinamide $\left((\mathrm{CN})_{2} \mathrm{Cbi}\right)$ and its phosphate analog $\left((\mathrm{CN})_{2} \mathrm{Cbi}-\mathrm{P}\right)$ as well as cyanoaqua cobyrinic acid heptamethylester $\left((\mathrm{CN})\left(\mathrm{H}_{2} \mathrm{O}\right) \mathrm{Cby}(\mathrm{OMe})_{7}\right)$ (Figure 1). Due to the fact that corrinoid molecules possess sufficiently high rotational strength in the range of ROA excitation (532 nm), it was possible to record their RROA spectra. They showed several distinct spectral features enabling the differentiation of the studied compounds, in contrast to other methods, like UV-Vis, ECD, and resonance Raman spectroscopy.

\section{Results and Discussion}

The UV-Vis and ECD spectra of vitamin $B_{12}$ in an aqueous solution are presented, along with spectra of its truncated derivatives in Figure 2 and Figure S1 (Supplementary Materials). The absorption spectra of $(\mathrm{CN}) \mathrm{Cbl}[40]$ and some of its incomplete analogs in organic and non-organic solvents $[18,37,48,49]$ have been previously reported and they agree well with the spectra obtained in this study. The spectral profiles and electronic properties of corrinoid molecules slightly change depending on the solvent used $[36,48]$. As generally proposed and subsequently confirmed, the UV-Vis spectra are mostly dominated by intense corrin-based $\pi \rightarrow \pi^{*}$ transitions, since $(\mathrm{CN}) \mathrm{Cbl}$ and its derivatives closely resemble those possessing metal-free corrin rings [40,50].

It is also worth emphasizing that the UV-Vis spectra of $(\mathrm{CN}) \mathrm{Cbl}$ and its truncated analogs presented several similarities: the main absorption bands $\alpha / \beta, D$, and $\gamma$ appeared in the spectra of all studied species and are of comparable intensities (Figure 2). The manifestation of these unique absorption features leads to the classification of the studied corrinoids' UV-Vis spectra to the so-called normal [37,51]. Nevertheless, based on the changes in the color of the $(\mathrm{CN}) \mathrm{Cbl}$ solution in water compared to its incomplete derivatives: from red for cobalamin to rosy for $(\mathrm{CN})\left(\mathrm{H}_{2} \mathrm{O}\right) \mathrm{Cby}(\mathrm{OMe})_{7}$ and purple for $(\mathrm{CN})_{2} \mathrm{Cbi}$ and $(\mathrm{CN})_{2} \mathrm{Cbi}-\mathrm{P}$, the absorption spectra of these compounds differs with regard to the position (wavelength) of distinctive bands. In the case of native $(\mathrm{CN}) \mathrm{Cbl}$, two prominent bands occurred in the $\alpha / \beta$ visible region with the more intense counterpart at $550 \mathrm{~nm}$ and less intense at $521 \mathrm{~nm}$ being the electronic origin and vibrational progression, respectively, of the electronic excitation from the orbital HOMO to the orbital LUMO of the corrin macrocycle. The absorption band of the highest intensity in the near-UV spectral region was centered at $361 \mathrm{~nm}$ and it was assigned to a transition with predominant corrin $\pi \rightarrow \pi^{*}$ nature $[27,40]$. The " $\gamma$-band-type" transition results are generally from mixing between Co $3 \mathrm{~d}$ and corrin-based $\pi$ orbitals that produce destabilization of all 3 d orbitals $[24,40]$. 

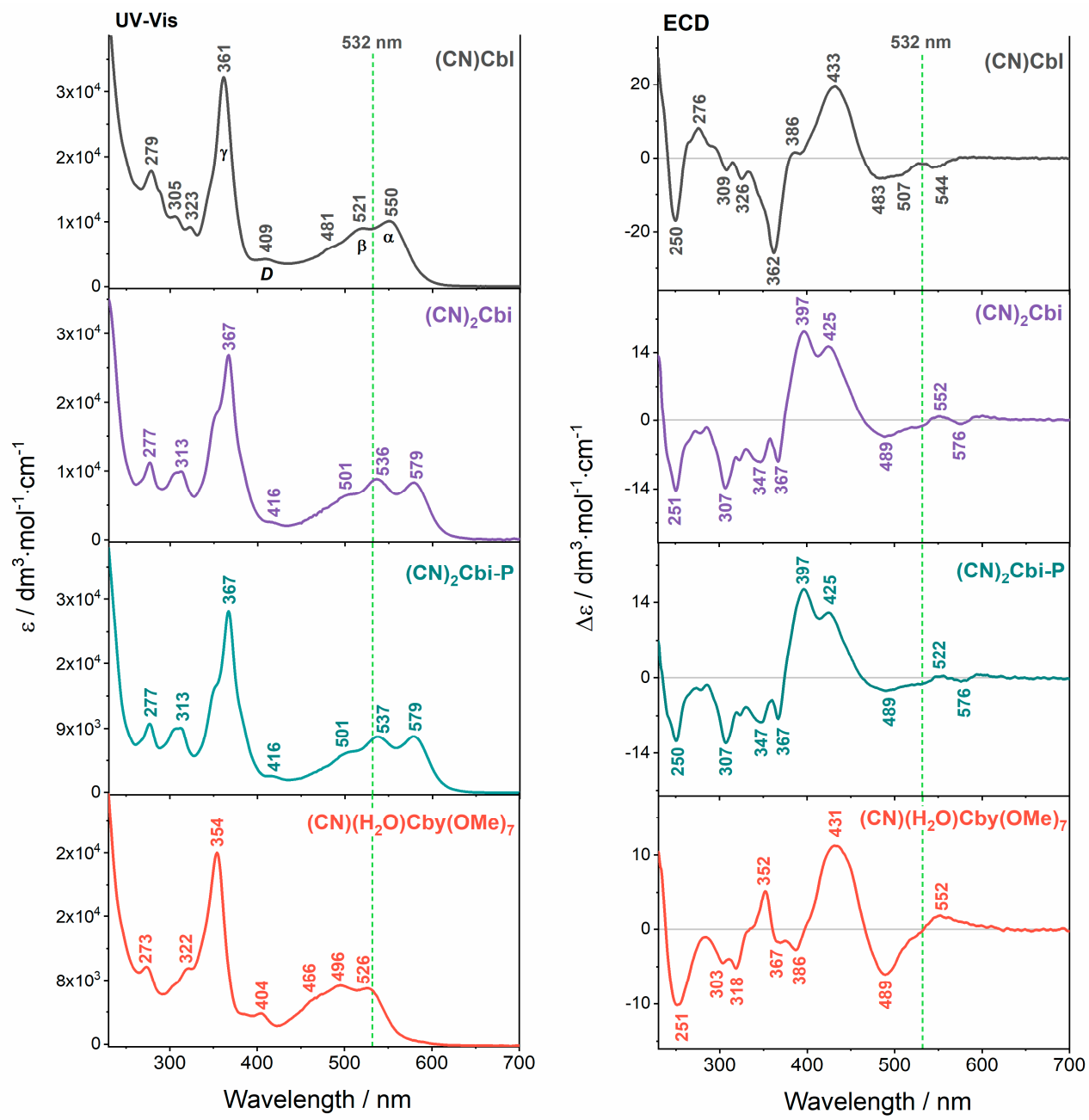

Figure 2. Experimental UV-Vis and ECD spectra of vitamin $B_{12}$ and its truncated analogs. The green dotted line indicates the excitation wavelength of the ROA laser.

On the other hand, replacing the bulky Dmb base with $\mathrm{CN}^{-}$or an $\mathrm{H}_{2} \mathrm{O}$ ligand perturbs the electronic structure of corrinoids. In the context of truncated vitamins, a few spectral features can be pointed out: (1) the $\alpha$-band has comparable intensity to that of the $\beta$ ones; (2) changing the lower axial ligand by $\mathrm{CN}^{-}$results in red-shift of the $\alpha$ and $\beta$ bands, except for cyanoaqua cobyrinic acid derivative; (3) the low-intensity band referred to as $D$, which was present in the normal spectra of both cobalamin and truncated vitamins, shifts towards higher or lower wavelengths compared to the $(\mathrm{CN}) \mathrm{Cbl}(409 \mathrm{~nm})$, respectively for $(\mathrm{CN})_{2} \mathrm{Cbi}$ and its phosphate analog $(416 \mathrm{~nm})$ and $(\mathrm{CN})\left(\mathrm{H}_{2} \mathrm{O}\right) \mathrm{Cby}(\mathrm{OMe})_{7}(404 \mathrm{~nm})$; (4) a more pronounced shoulder on the higher energy side of the $\gamma$ band was observed upon replacing the axial Dmb moiety with a different group. It is evident that the energies of $\alpha, \beta$, and $\gamma$ bands vary depending on the pair of axial substituents attached to the cobalt ion, in other words, the blue-shift of dominant bands can be noticed with increasing fashion in the donation of electrons by axial ligands $\left(\left[\mathrm{CN}^{-}, \mathrm{CN}^{-}\right]<\left[\mathrm{CN}^{-}, \mathrm{H}_{2} \mathrm{O}\right]\right)$. The blue-shifted absorption in the spectrum of $(\mathrm{CN})\left(\mathrm{H}_{2} \mathrm{O}\right) \mathrm{Cby}(\mathrm{OMe})_{7}$ relative to that of $(\mathrm{CN}) \mathrm{Cbl}$ can be attributed to the elimination of $\sigma$-antibonding interactions, producing a species-dependent stabilization of the HOMO compared to the LUMO orbital [24].

The experimental ECD spectra presented in Figure 2 show enhanced sensitivity over UV-Vis spectroscopy in probing slight changes in the electronic structure of cobalamin and its truncated derivatives, which are a consequence of an exchange of an axial ligand incorporation to the central cobalt ion. The ECD spectra of all studied corrinoids were dominated by an intense and broad positive signal between 400 and $500 \mathrm{~nm}$ and a series of negative bands in the range of 240 to $370 \mathrm{~nm}$ (the spectrum 
of $(\mathrm{CN})\left(\mathrm{H}_{2} \mathrm{O}\right) \mathrm{Cby}(\mathrm{OMe})_{7}$ with a positive band at $352 \mathrm{~nm}$ is an exception). The spectral signatures are different e.g., (CN)Cbl vs. incomplete analogs. Presumably, the unique variances between chiroptical ECD spectra of the parent vitamin and its derivatives are a consequence of the replacement of the bulky $\mathrm{Dmb}$ base (a moderately strong $\sigma$-donor) with significantly smaller $\mathrm{CN}^{-}$(moderate $\sigma$ - and $\pi$-donor) or $\mathrm{H}_{2} \mathrm{O}$ ligand (rather weakly $\sigma$ - and $\pi$-donor) [40], which leads to a greater deformation of the corrin ring. Interestingly, the UV-Vis and ECD spectra of two cobinamide species $\left((\mathrm{CN})_{2} \mathrm{Cbi}\right.$ and $\left.(\mathrm{CN})_{2} \mathrm{Cbi}-\mathrm{P}\right)$ were identical, superimposable curves. This proves that both spectroscopic methods (UV-Vis and ECD) were not sufficiently sensitive to subtle changes in the structure of truncated cobinamide bearing a free phosphate group vs. its native form. The minor changes in the absorption intensities and rotational strength of $(\mathrm{CN})_{2} \mathrm{Cbi}$ and $(\mathrm{CN})_{2} \mathrm{Cbi}-\mathrm{P}$ species can be exclusively detected.

RR spectra of cobalamins and cobinamides were strongly dominated by the corrin-based vibrational modes, with the most intense band centered at $\sim 1501 \mathrm{~cm}^{-1}$ associated with the long-axis polarized corrin macrocycle mode, $v_{\mathrm{LA}}$, which was mainly attributed to the in-phase $\mathrm{C}=\mathrm{C}$ and $\mathrm{C}=\mathrm{N}$ stretching along the longer (C5-Co-C15) corrin ring axis (Figure 1). Another equally important spectral feature, close to the $v_{\mathrm{LA}}$, was the short-axis polarized corrin ring motion: $v_{\mathrm{SA}}$, located between 1543 and $1549 \mathrm{~cm}^{-1}$ and correlated with the $\mathrm{C}=\mathrm{C}$ and $\mathrm{C}=\mathrm{N}$ stretching along the shorter $(\mathrm{Co}-\mathrm{C} 10)$ corrin ring axis, and two other corrin macrocycle $C=C$ stretching modes located above $1560 \mathrm{~cm}^{-1}$ [30]. The spectral region between 1300 and $1400 \mathrm{~cm}^{-1}$ can be generally assigned to the $\mathrm{CH}_{3}$ and $\mathrm{CH}_{2}$ bending vibrations, while the 1100 to $1300 \mathrm{~cm}^{-1}$ region to the $\mathrm{CH}_{2}$ twisting and wagging, $\mathrm{CH}$ bending, as well as the corrin ligand C-C and C-N stretching motions [41]. Moreover, the low wavenumber region below $550 \mathrm{~cm}^{-1}$ was more sensitive to the replacement of an axial ligand attached to the cobalt ion, and it was dominated by the Co-C stretching vibrations located around $500 \mathrm{~cm}^{-1}$, that was more intense for an alkyl substituted $\mathrm{Co}$, as well as $\mathrm{Co}-\mathrm{C} \equiv \mathrm{N}$ bending or $\mathrm{C} \equiv \mathrm{N}$ twisting modes, present for the analogs with the $\mathrm{CN}^{-}$axial ligand (Table 1) $[30,41]$.

Table 1. Assignments of the most characteristic Raman and ROA bands of vitamin $\mathrm{B}_{12}((\mathrm{CN}) \mathrm{Cbl})$ [41].

\begin{tabular}{|c|c|c|}
\hline $\operatorname{Raman} / \mathrm{cm}^{-1}$ & $\mathrm{ROA} / \mathrm{cm}^{-1}$ & Assignments \\
\hline 1602 & - & $\mathrm{C}=\mathrm{C} \operatorname{str}(14-15), \mathrm{C}=\mathrm{N} \operatorname{str}(16-24)$ \\
\hline 1577 & $1578(+)$ & $\mathrm{C}=\mathrm{C} \operatorname{str}(5-6 ; 10-11), \mathrm{C}-\mathrm{H}$ bend $(10), \mathrm{C}=\mathrm{N}$ str $(16-24 ; 4-21)$ \\
\hline 1543 & $1546(+)$ & $\mathrm{C}=\mathrm{C} \operatorname{str}(5-6 ; 10-11 ; 14-15), \mathrm{C}=\mathrm{N} \operatorname{str}(9-22 ; 11-23 ; 16-24 ; 4-21)$ \\
\hline 1501 & $1501(+)$ & $\begin{array}{c}\mathrm{C}=\mathrm{C} \operatorname{str}(5-6 ; 9-10 ; 14-15), \mathrm{C}=\mathrm{N} \text { str }(4-21 ; 11-23 ; 16-24 ; \mathrm{B} 2-\mathrm{B} 1 ; \mathrm{B} 2-\mathrm{B} 3), \mathrm{C}-\mathrm{H} \\
\text { bend (10; } \mathrm{B} 2), \mathrm{CH}_{3} \text { bend asym, } \mathrm{CH}_{2} \text { bend (scissoring) }\end{array}$ \\
\hline 1350 & $1344(+)$ & $\mathrm{CH}_{2}$ wagg, $\mathrm{CH}$ bend \\
\hline 1228 & $1228(+)$ & $\mathrm{CH}_{2}$ wagg, $\mathrm{CH}$ bend, $\mathrm{NH}$ bend, $\mathrm{CH}_{3}$ rock \\
\hline 1205 & $1205(+)$ & $\mathrm{C}-\mathrm{C} \operatorname{str}$ (corrin ring), $\mathrm{CH}_{2}$ twist, $\mathrm{CH}$ bend, $\mathrm{CH}_{3}$ rock \\
\hline 1168 & $1168(+)$ & 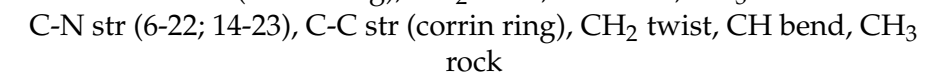 \\
\hline $1105 s$ & $1109(-)$ & $\mathrm{C}-\mathrm{N} \operatorname{str}(6-22 ; 14-23), \mathrm{NH}_{2}$ rock, $\mathrm{CH}_{2}$ twist, $\mathrm{CH}$ bend \\
\hline 890 & $\begin{array}{l}895 \mathrm{~s}(+) \\
877(+)\end{array}$ & $\begin{array}{c}\mathrm{CH}_{3} \text { and } \mathrm{CH}_{2} \text { rock, } \mathrm{C}-\mathrm{C} \operatorname{str}(7-37 ; 37-38 ; 8-9 ; 6-7 ; 8-41 ; 9-10 ; 12-46), \mathrm{Co}-\mathrm{N} \\
\operatorname{str}(22 ; 23), \mathrm{C}-\mathrm{C} \operatorname{str}(1-2 ; 1-19 ; 1-20 ; 3-4 ; 4-5 ; 5-35 ; 6-7 ; 7-8 ; 7-36 ; 31-32), \\
\text { C-N str }(1-21)\end{array}$ \\
\hline 732 & $732(+)$ & $\begin{array}{c}\mathrm{CH}_{3} \text { and } \mathrm{CH}_{2} \text { rock, corrin ring tors and bend, } \mathrm{NH}_{2} \text { twist, } \mathrm{CCC} \text { bend, } \\
\mathrm{CC}, \mathrm{CN} \text { tors, benzimidazole } \mathrm{C}-\mathrm{C} \text { str }\end{array}$ \\
\hline 696 & $695(-)$ & $\mathrm{CH}_{2}$ rock, $\mathrm{NH}_{2}$ twist, corrin ring tors and bend, $\mathrm{CCC}$ bend, $\mathrm{CC}, \mathrm{CN}$ tors \\
\hline 636 & $635(+)$ & $\mathrm{NH}_{2}$ twist, corrin ring tors and bend \\
\hline 584 & $585(+)$ & $\mathrm{NH}_{2}$ twist \\
\hline 518 & $518(+)$ & corrin ring tors and bend, $\mathrm{NH}_{2}$ twist, $\mathrm{CCC}$ bend, $\mathrm{CC}, \mathrm{CN}$ tors \\
\hline 496 & $497(-)$ & $\begin{array}{l}\mathrm{Co}-\mathrm{C} \equiv \mathrm{N} \text { bend, } \mathrm{C} \equiv \mathrm{N} \text { twist, corrin ring tors and bend, benzimidazole } \\
\text { ring breathing, } \mathrm{Co}-\mathrm{N} \text { bend (B3), } \mathrm{O}-\mathrm{H} \text { bend ( } \mathrm{R} \text { ) }\end{array}$ \\
\hline 427 & $429(+)$ & $\begin{array}{l}\mathrm{Co}-\mathrm{C} \equiv \mathrm{N} \text { bend, corrin ring tors and bend, } \mathrm{CCN}, \mathrm{CNC} \text { bend, } \mathrm{CC}, \mathrm{CN} \text { tors, } \\
\qquad \mathrm{C} \equiv \mathrm{N} \text { twist, } \mathrm{O}-\mathrm{H} \text { bend (7R) }\end{array}$ \\
\hline
\end{tabular}

Abbreviations: str-stretching; bend—bending; sym-symmetric; asym-asymmetric; wagg-wagging; twist—-twisting; rock—rocking; tors—-torsion; s-shoulder, $(+)$ and (-)—positive and negative ROA intensities, numbers in brackets denote atoms involved in vibrations accordingly to the Figure 1 numeration. 
Experimental RR and RROA spectra of $(\mathrm{CN}) \mathrm{Cbl}$ along with its truncated analogs are presented in Figure 3. Contrary to the UV-Vis spectra, Raman spectra of all three incomplete vitamin $B_{12}$ derivatives were almost the same, particularly between 1650 and $1150 \mathrm{~cm}^{-1}$, where the most intense bands are located. Undoubtedly, Raman spectra of $(\mathrm{CN})_{2} \mathrm{Cbi}$ and $(\mathrm{CN})_{2} \mathrm{Cbi}-\mathrm{P}$ species were identical in the whole spectral range, similarly to their UV-Vis and ECD spectra, because their structures differ only at distant places from the chromophore. However, in the case of the third analog, $(\mathrm{CN})\left(\mathrm{H}_{2} \mathrm{O}\right) \mathrm{Cby}(\mathrm{OMe})_{7}$ (Figure 1), one can find a few modest differences in the Raman profile, especially below $900 \mathrm{~cm}^{-1}$ (Figure 4), that are related mostly to the replacement of the axial ligand $\mathrm{CN}$ by $\mathrm{H}_{2} \mathrm{O}$. In general, consistent with the previous reports [32,41], RR spectra of cobalamins equipped with different axial ligands were strikingly similar, but at the same time, their electronic spectra (UV-Vis and ECD) differed significantly.
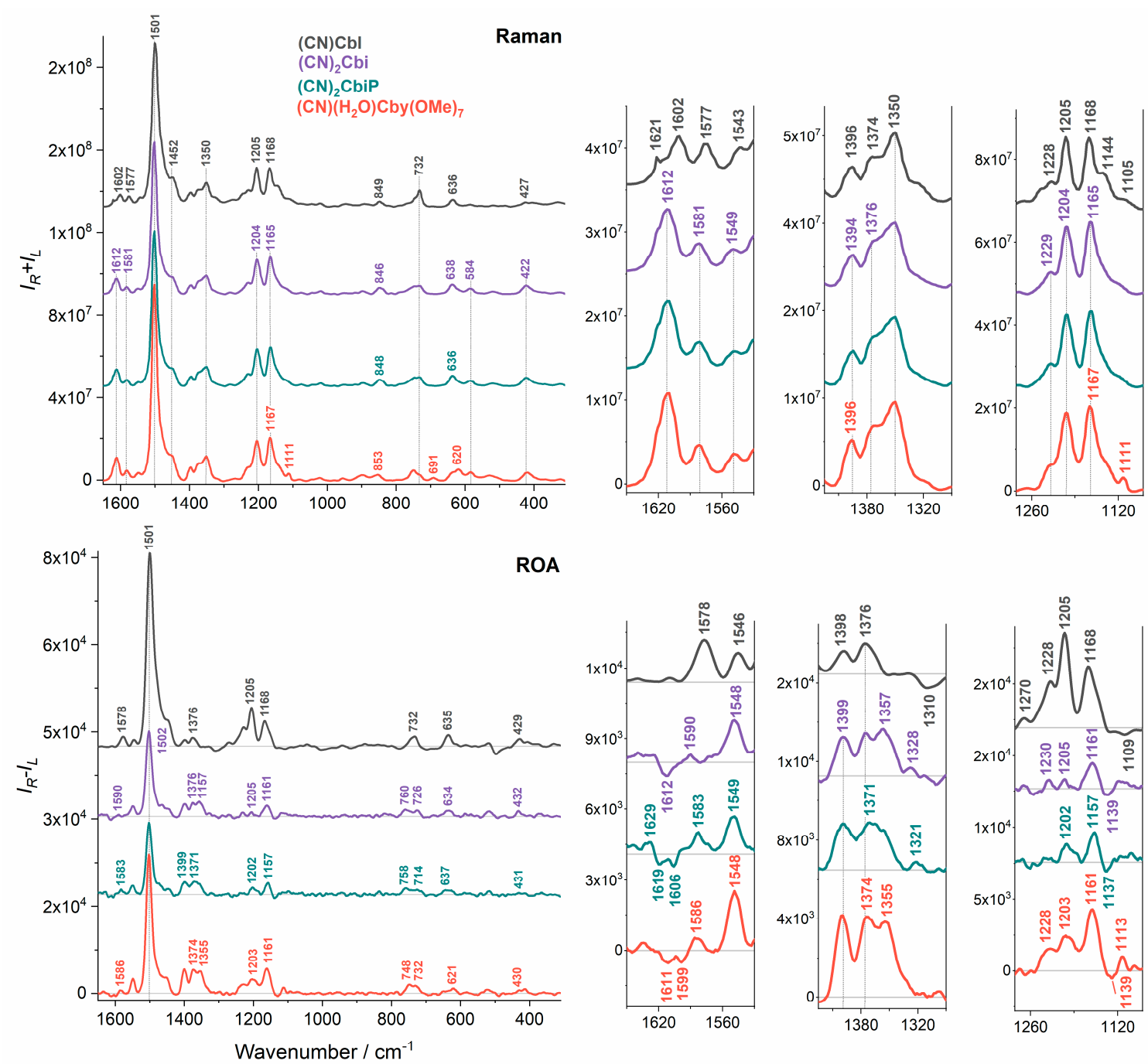

Figure 3. Experimental Raman and RROA spectra of vitamin $\mathrm{B}_{12}$ and its truncated analogs. 


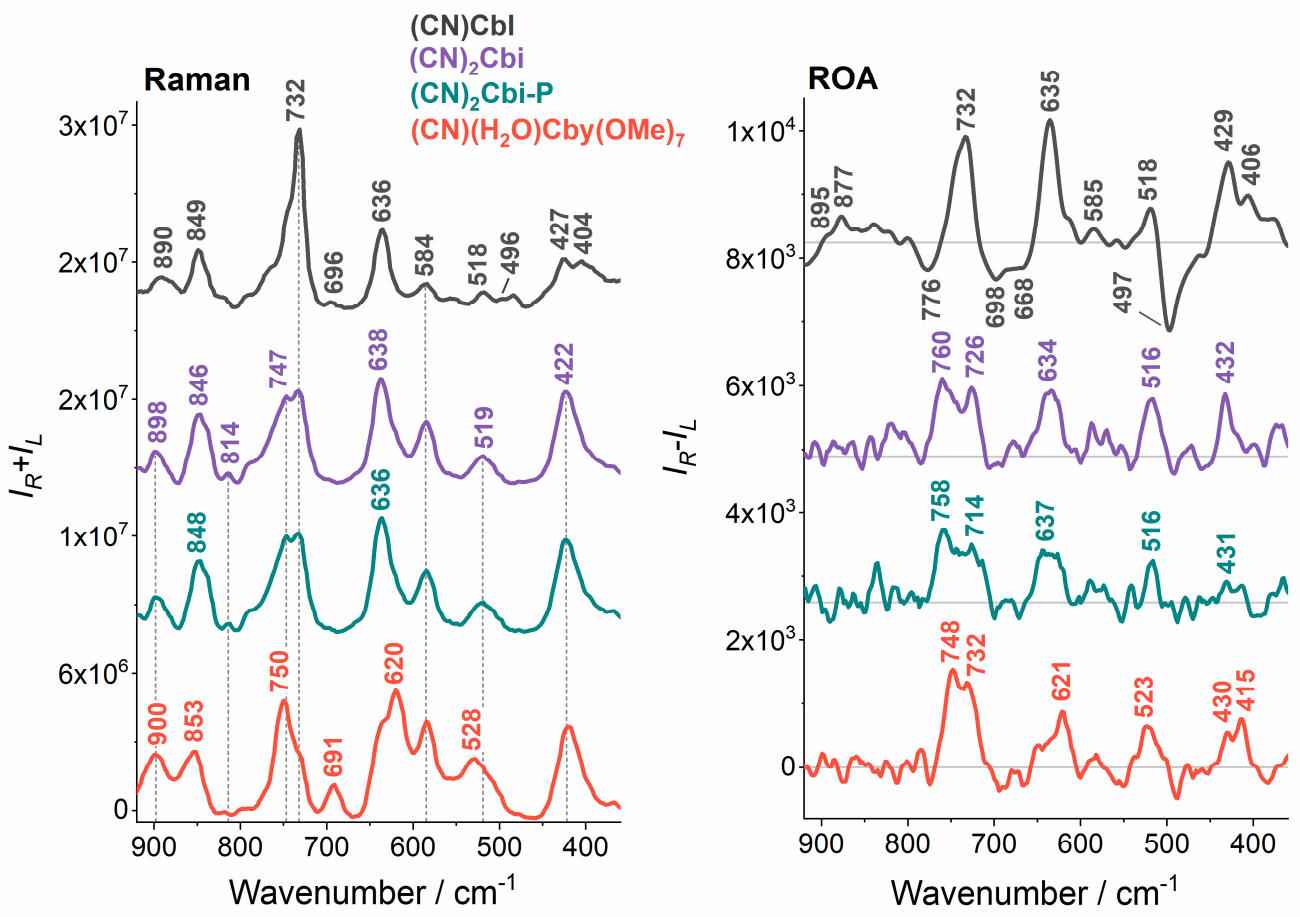

Figure 4. Detailed comparison of Raman and ROA spectra of vitamin $\mathrm{B}_{12}$ and its truncated analogs in the 900 to $350 \mathrm{~cm}^{-1}$ spectral region.

The first striking feature of the RR spectrum of $(\mathrm{CN})\left(\mathrm{H}_{2} \mathrm{O}\right) \mathrm{Cby}(\mathrm{OMe})_{7}$ was a low-intensity band, centered at $1111 \mathrm{~cm}^{-1}$, that was less resolved for the other analogs and was present on their spectra as a shoulder (Figure 3). According to our recent study of cobalamins [41], that band is most likely involved in the corrin ring $\mathrm{C}-\mathrm{N}$ stretching motions, but taking into consideration an additional seven -OMe groups in the $(\mathrm{CN})\left(\mathrm{H}_{2} \mathrm{O}\right) \mathrm{Cby}(\mathrm{OMe})_{7}$ structure, one can say that the spectral feature may also be assigned to the $\mathrm{O}-\mathrm{CH}_{3}$ vibrational stretching mode of $\mathrm{CO}_{2}$ Me groups. Other spectral changes were observed between 900 and $500 \mathrm{~cm}^{-1}$ (Figure 4). Two closely lying bands at $\sim 900$ and $\sim 850 \mathrm{~cm}^{-1}$ related to the $\mathrm{CH}_{3}$ rocking and $\mathrm{C}-\mathrm{C}$ stretching of the side chains had the same intensity for $(\mathrm{CN})\left(\mathrm{H}_{2} \mathrm{O}\right) \mathrm{Cby}(\mathrm{OMe})_{7}$, while in the case of $(\mathrm{CN}) \mathrm{Cbl},(\mathrm{CN})_{2} \mathrm{Cbi}$ and its phosphate derivative, the intensity of the $\sim 900 \mathrm{~cm}^{-1}$ band was twice as low as for the one at $\sim 850 \mathrm{~cm}^{-1}$. In the 730 to $750 \mathrm{~cm}^{-1}$ region, which is connected mostly with the $\mathrm{CH}_{3}, \mathrm{CH}_{2}$ rocking and corrin ring torsions, two separated bands were present for both $(\mathrm{CN})_{2} \mathrm{Cbi}$ and $(\mathrm{CN})_{2} \mathrm{CbiP}$ species $\left(732 \mathrm{~cm}^{-1}, 747 \mathrm{~cm}^{-1}\right)$, and one spectral feature centered at $750 \mathrm{~cm}^{-1}$ with a shoulder at $732 \mathrm{~cm}^{-1}$ for $(\mathrm{CN})\left(\mathrm{H}_{2} \mathrm{O}\right) \mathrm{Cby}(\mathrm{OMe})_{7}$ (Table 1). Conversely, in the RR spectrum of $(\mathrm{CN}) \mathrm{Cbl}$, the band at $732 \mathrm{~cm}^{-1}$ was more prominent while $750 \mathrm{~cm}^{-1}$ was less intense and hidden as a shoulder. Moreover, the $691 \mathrm{~cm}^{-1}$ band was much more intense for $(\mathrm{CN})\left(\mathrm{H}_{2} \mathrm{O}\right) \mathrm{Cby}(\mathrm{OMe})_{7}$ than for $(\mathrm{CN}) \mathrm{Cbl}$ and was not present for the other analogs. Furthermore, the band located at $\sim 637 \mathrm{~cm}^{-1}$ for $(\mathrm{CN}) \mathrm{Cbl}$, $(\mathrm{CN})_{2} \mathrm{Cbi}$ and $(\mathrm{CN})_{2} \mathrm{Cbi}-\mathrm{P}$ downshifted to $620 \mathrm{~cm}^{-1}$ for $(\mathrm{CN})\left(\mathrm{H}_{2} \mathrm{O}\right) \mathrm{Cby}(\mathrm{OMe})_{7}$ and the intensity of the $584 \mathrm{~cm}^{-1}$ band increased in the order $(\mathrm{CN}) \mathrm{Cbl}<(\mathrm{CN})_{2} \mathrm{Cbi},(\mathrm{CN})_{2} \mathrm{Cbi}-\mathrm{P}<(\mathrm{CN})\left(\mathrm{H}_{2} \mathrm{O}\right) \mathrm{Cby}(\mathrm{OMe})_{7}$. Last but not least, a shift was observed for the low-frequency band associated with the Co-C [30] or generally Co-L [41] stretching vibrations, from 518 and $484 \mathrm{~cm}^{-1}$ for $(\mathrm{CN}) \mathrm{Cbl}$ or $519 \mathrm{~cm}^{-1}$ for $(\mathrm{CN})_{2} \mathrm{Cbi}$ and $(\mathrm{CN})_{2} \mathrm{Cbi}-\mathrm{P}$ to $528 \mathrm{~cm}^{-1}$ for $(\mathrm{CN})\left(\mathrm{H}_{2} \mathrm{O}\right) \mathrm{Cby}(\mathrm{OMe})_{7}$, which was due to the change of the axial ligand from $\mathrm{Dmb}$ or $\mathrm{CN}^{-}$to $\mathrm{CN}^{-}$or $\mathrm{H}_{2} \mathrm{O}$.

Most of the RR spectral variations of the truncated analogs of $(\mathrm{CN}) \mathrm{Cbl}$ result from the replacement of the lower axial ligand or are a consequence of the corrin ring conformational changes. However, as already mentioned, there were no evident differences between RR spectra of $(\mathrm{CN})_{2} \mathrm{Cbi}$ and $(\mathrm{CN})_{2} \mathrm{Cbi}-\mathrm{P}$, and it is therefore impossible to distinguish these two compounds, neither by RR, nor by UV-Vis or ECD spectroscopies. If we compare the RR spectrum of $(\mathrm{CN}) \mathrm{Cbl}$ with its truncated 
analogs, observed differences were even more pronounced, thus replacement of the bulky Dmb moiety by a smaller lower axial ligand, e.g., $\mathrm{CN}^{-}$, affects the corrin ring conformation to a higher extent. This is in accordance with the change in the intensity and position of the $v_{\mathrm{SA}}$ band and two other corrin ring stretching modes located above $1500 \mathrm{~cm}^{-1}$. First, we observed a pronounced shift of bands from $1543\left(v_{\mathrm{SA}}\right), 1577$, and $1602 \mathrm{~cm}^{-1}$ for $(\mathrm{CN}) \mathrm{Cbl}$, to 1549,1581 , and $1612 \mathrm{~cm}^{-1}$, respectively, for all truncated analogs (Figure 3). Another change can be found in the bands' intensity, which for (CN)Cbl was more or less similar for all three vibrational modes, while for truncated analogs the $1612 \mathrm{~cm}^{-1}$ band was much more intense than for the remaining two.

Experimental RROA spectra of all measured corrinoids are mostly positive, with an addition of a few negative, low-intensity bands (Figure 3). Analogously with our previous study in which we investigated cobalamins possessing a variously modified upper axial position [41], RROA spectra of truncated analogs of vitamin $\mathrm{B}_{12}$ are also bisignate, as a result of the excitation ( $532 \mathrm{~nm}$ ) involving several closely-lying electronic states, with both negative and positive ECD. Positive RROA bands were due to the strong resonance upon the corrin-based $\pi \rightarrow \pi^{*}$ transitions, characterized by negative ECD, that were located at 576 and $489 \mathrm{~nm}$ for $(\mathrm{CN})_{2} \mathrm{Cbi}$ and $(\mathrm{CN})_{2} \mathrm{Cbi}-\mathrm{P}$, and at $489 \mathrm{~nm}$ for $(\mathrm{CN})\left(\mathrm{H}_{2} \mathrm{O}\right) \mathrm{Cby}(\mathrm{OMe})_{7}$. Presumably, negative RROA bands were most likely the result of the resonance upon the positive ECD electronic transition, located at $425 \mathrm{~nm}$ for $(\mathrm{CN})_{2} \mathrm{Cbi}$ and $(\mathrm{CN})_{2} \mathrm{Cbi}-\mathrm{P}$, and at $431 \mathrm{~nm}$ for $(\mathrm{CN})\left(\mathrm{H}_{2} \mathrm{O}\right) \mathrm{Cby}(\mathrm{OMe})_{7}$ (Figure 2). ECD/UV-Vis (g-factor) ratios of the resonant electronic transitions and RROA/RR (CIDs) ratios, as expected for most cases, did not obey the SES relation i.e., CID $=-1 / 2 g$-factor, due to the resonance via multiple electronic states (Supplementary Materials, Tables S1 and S2).

In contrast to RR spectroscopy, which provided spectra where no changes could be found between $(\mathrm{CN})_{2} \mathrm{Cbi}$ and $(\mathrm{CN})_{2} \mathrm{Cbi}-\mathrm{P}$ analogs, and only minor changes between $(\mathrm{CN})_{2} \mathrm{Cbi}$ and $(\mathrm{CN})\left(\mathrm{H}_{2} \mathrm{O}\right) \mathrm{Cby}(\mathrm{OMe})_{7}$ species were present, the RROA spectroscopy revealed to be superior. Similarly, as for the RR, RROA spectra of all truncated analogs were comparable in the corrin ring stretching region (1650 to $\left.1450 \mathrm{~cm}^{-1}\right)$, while the $(\mathrm{CN}) \mathrm{Cbl}$ spectrum was noticeably different. However, unlike the position of the positive RROA $v_{\mathrm{SA}}$ mode $\left(\sim 1548 \mathrm{~cm}^{-1}\right)$, which was the same for all truncated analogs, the corrin ring motion had altered position and intensity for the studied analogs. We can clearly see that the intensity ratio of the 1548 and $1590 \mathrm{~cm}^{-1}$ bands for $(\mathrm{CN})_{2} \mathrm{Cbi}$ was much higher than the corresponding intensity ratio of $1549 / 1583 \mathrm{~cm}^{-1}$ for $(\mathrm{CN})_{2} \mathrm{Cbi}-\mathrm{P}$. What is more, negative $1612 \mathrm{~cm}^{-1}$ corrin ring stretching motion for $(\mathrm{CN})_{2} \mathrm{Cbi}$ was split into two modes, both for the $(\mathrm{CN})_{2} \mathrm{Cbi}-\mathrm{P}\left(1612,1606 \mathrm{~cm}^{-1}\right)$ and $(\mathrm{CN})\left(\mathrm{H}_{2} \mathrm{O}\right) \mathrm{Cby}(\mathrm{OMe})_{7}\left(1611,1599 \mathrm{~cm}^{-1}\right)$. Contrary to the RR spectra, some subtle differences were also found in the $\mathrm{CH}_{3}$ and $\mathrm{CH}_{2}$ bending vibrations region (1400 to $\left.1300 \mathrm{~cm}^{-1}\right)$ (Table 1). For $(\mathrm{CN})_{2} \mathrm{Cbi}$ and $(\mathrm{CN})\left(\mathrm{H}_{2} \mathrm{O}\right) \mathrm{Cby}(\mathrm{OMe})_{7}$, one can see two distinct modes at 1376 and $1357 \mathrm{~cm}^{-1}$ for the first one, as well as 1374 and $1355 \mathrm{~cm}^{-1}$ for the second one, while the $(\mathrm{CN})_{2} \mathrm{Cbi}-\mathrm{P}$ possess only one mode at $1371 \mathrm{~cm}^{-1}$. RROA spectra of $(\mathrm{CN})_{2} \mathrm{Cbi}$ and $(\mathrm{CN})_{2} \mathrm{Cbi}-\mathrm{P}$ contained a band located at $1328 / 1321 \mathrm{~cm}^{-1}$, which was not present in the spectrum of $(\mathrm{CN})\left(\mathrm{H}_{2} \mathrm{O}\right) \mathrm{Cby}(\mathrm{OMe})_{7}$. The most distinctive was the 1300 to $1100 \mathrm{~cm}^{-1}$ spectral region, where for the $(\mathrm{CN})_{2} \mathrm{Cbi}$, two separated, similarly intense, positive bands at 1230 and $1205 \mathrm{~cm}^{-1}$ could be found, while for $(\mathrm{CN})_{2} \mathrm{Cbi}-\mathrm{P}$ only one of higher intensity than for $(\mathrm{CN})_{2} \mathrm{Cbi}$ was present $\left(1202 \mathrm{~cm}^{-1}\right)$. Moreover, two bands were present $\left(1228 \mathrm{~cm}^{-1}, 1203 \mathrm{~cm}^{-1}\right)$ for the $(\mathrm{CN})\left(\mathrm{H}_{2} \mathrm{O}\right) \mathrm{Cby}(\mathrm{OMe})_{7}$ but the $1203 \mathrm{~cm}^{-1}$ was higher in intensity. The $1230 \mathrm{~cm}^{-1}$ band was related mostly to $\mathrm{CH}_{2}$ wagging, and $\mathrm{CH}$ bending modes, while $1205 \mathrm{~cm}^{-1}$ to corrin ring $\mathrm{C}-\mathrm{C}$ stretching and $\mathrm{CH}_{2}$ twisting [41]. This means that the presence of a phosphate group caused the structural changes around the side chains containing $\mathrm{CH}_{2}$ groups, as well as affecting the conformation of the corrin ring. A low wavenumber region in the RROA spectra is also distinctive for all incomplete analogs of vitamin $\mathrm{B}_{12}$, however, due to the low intensity of registered bands and low signal to noise ratio $(\mathrm{S} / \mathrm{N})$, the interpretation was not as straightforward as for other spectral regions (Figure 4). The major difference between truncated analogs, was a much higher intensity $432 \mathrm{~cm}^{-1}$ positive band for $(\mathrm{CN})_{2} \mathrm{Cbi}$ compared to $(\mathrm{CN})_{2} \mathrm{Cbi}-\mathrm{P}$ and $(\mathrm{CN})\left(\mathrm{H}_{2} \mathrm{O}\right) \mathrm{Cby}(\mathrm{OMe})_{7}$, that was ascribed to $\mathrm{Co}-\mathrm{C} \equiv \mathrm{N}$ bending, $\mathrm{C} \equiv \mathrm{N}$ twisting modes and also to corrin ring torsion and bending vibrational modes. Between 900 and $600 \mathrm{~cm}^{-1}$, RROA spectra of $(\mathrm{CN})_{2} \mathrm{Cbi}$ and $(\mathrm{CN})_{2} \mathrm{Cbi}-\mathrm{P}$ were almost the same and, 
similarly to the RR, the RROA spectrum of $(\mathrm{CN})\left(\mathrm{H}_{2} \mathrm{O}\right) \mathrm{Cby}(\mathrm{OMe})_{7}$ had more pronounced differences compared to the remaining truncated analogs.

Surprisingly, noticeable changes in the resonance condition (a shift of the $\alpha / \beta$ electronic absorption bands with respect to the ROA $532 \mathrm{~nm}$ excitation line) of truncated vitamins compared to the parent vitamin $B_{12}$, did not change the overall RR and RROA profiles of the studied compounds. However, slight, but not negligible, differences could be found in the case of intensity ratios of $\mathrm{RROA} / \mathrm{RR}$ (CID values) of the corresponding bands. What we have observed is that for $(\mathrm{CN})_{2} \mathrm{Cbi}$ and $(\mathrm{CN})_{2} \mathrm{CbiP}$, where the $\alpha / \beta$ electronic bands showed the bathochromic shift compared to the $(\mathrm{CN}) \mathrm{Cbl}$ spectra, the CID ratios of $v_{\mathrm{LA}}\left(1501 \mathrm{~cm}^{-1}\right)$ were more than two times smaller than for the $(\mathrm{CN}) \mathrm{Cbl}$. $(\mathrm{CN})_{2} \mathrm{Cbi}$ and $(\mathrm{CN})_{2} \mathrm{CbiP} v_{\mathrm{LA}} \mathrm{CID}$ ratios equal $2.0 \times 10^{-4}$ and $1.6 \times 10^{-4}$, respectively, while for the $(\mathrm{CN}) \mathrm{Cbl}$ it was $4.0 \times 10^{-4}$ (Table S2). In the case of $(\mathrm{CN})\left(\mathrm{H}_{2} \mathrm{O}\right) \mathrm{Cby}(\mathrm{OMe})_{7}$, where the $\alpha / \beta$ electronic bands showed the hypsochromic shift, the CID ratio of $v_{\mathrm{LA}}$ was higher than that for the remaining truncated analogs $\left(2.5 \times 10^{-4}\right)$, but still lower than that for $(\mathrm{CN}) \mathrm{Cbl}$. This means that, in comparison to their parent $\mathrm{RR}$ spectra, $\mathrm{RROA}$ spectra of $(\mathrm{CN})_{2} \mathrm{Cbi}$ and $(\mathrm{CN})_{2} \mathrm{CbiP}$ were less resonantly enhanced than was observed for $(\mathrm{CN})\left(\mathrm{H}_{2} \mathrm{O}\right) \mathrm{Cby}(\mathrm{OMe})_{7}$ and especially for the $(\mathrm{CN}) \mathrm{Cbl}$. It was also clearly visible in Figure 3, where the RR intensity of $(\mathrm{CN}) \mathrm{Cbl}$ and incomplete analogs were comparable, while in the case of RROA, $(\mathrm{CN})_{2} \mathrm{Cbi}$, and $(\mathrm{CN})_{2} \mathrm{CbiP}$ spectra, they possessed much lower intensity compared to the $(\mathrm{CN})\left(\mathrm{H}_{2} \mathrm{O}\right) \mathrm{Cby}(\mathrm{OMe})_{7}$ and $(\mathrm{CN}) \mathrm{Cbl}$. Therefore, changing the resonance conditions did not affect $\mathrm{RR}$ and RROA profiles significantly but alters the RROA/RR intensity ratios.

\section{Materials and Methods}

\subsection{Sample Preparation}

Cyanocobalamin $((\mathrm{CN}) \mathrm{Cbl})$ was purchased from Sigma-Aldrich (Saint Louis, MO, USA). Truncated vitamin $\mathrm{B}_{12}$ derivatives: dicyanocobinamide $\left((\mathrm{CN})_{2} \mathrm{Cbi}\right)$, dicyanocobinamide phosphate $\left((\mathrm{CN})_{2} \mathrm{Cbi}-\mathrm{P}\right)$, and cyanoaqua cobyrinic acid heptamethylester $\left((\mathrm{CN})\left(\mathrm{H}_{2} \mathrm{O}\right) \mathrm{Cby}(\mathrm{OMe})_{7}\right)$ were synthesized according to reported procedures $[16,18]$.

\subsection{Spectroscopic Measurements (UV-Vis/ECD, Raman/ROA)}

Raman and ROA spectra of vitamin $\mathrm{B}_{12}$ and truncated vitamin $\mathrm{B}_{12}$ derivatives dissolved in distilled water $(c=0.1 \mathrm{mg} / \mathrm{mL})$ were registered using a ChiralRAMAN-2X spectrometer (BioTools Inc., Jupiter, FL, USA) at a resolution of $7 \mathrm{~cm}^{-1}$ in the range of 2500 to $250 \mathrm{~cm}^{-1}$ employing the excitation wavelength of $532 \mathrm{~nm}$. The spectra were measured in ROA quartz optical cells with anti-reflective coating. The laser power of $200 \mathrm{~mW}$, integration time of $4 \mathrm{~s}$ and $24 \mathrm{~h}$ (for (CN)Cbl) or $60 \mathrm{~h}$ (for $(\mathrm{CN})_{2} \mathrm{Cbi},(\mathrm{CN})_{2} \mathrm{Cbi}-\mathrm{P}$ and $\left.(\mathrm{CN})\left(\mathrm{H}_{2} \mathrm{O}\right) \mathrm{Cby}(\mathrm{OMe})_{7}\right)$ acquisition time was used for Raman and ROA measurements of studied compounds. For truncated cobalamin derivatives the longer accumulation time was used $(60 \mathrm{~h})$, due to the insufficient $\mathrm{S} / \mathrm{N}$ ratio after $24 \mathrm{~h}$ acquisition. Due to the limited stability of truncated cobalamin derivatives under laser irradiation (over $12 \mathrm{~h}$ ), the final $60 \mathrm{~h}$ spectra were averaged over five $12 \mathrm{~h}$ measurements (after rejection cosmic ray artifacts and an incorrect ROA compensation) of freshly prepared solutions. All solutions were passed through the Millex $^{\circledR}$ (Merck Millipore ${ }^{\mathrm{TM}}$, Burlington, MA, USA) syringe PTFE filters (pore size $0.2 \mu \mathrm{m}$ ) to remove solid impurities before running the measurement. Raman spectra were corrected by subtracting the spectrum obtained for the solvent using OPUS software (OPUS 7.2, Bruker Optik GmbH, Ettlingen, Germany). The baseline of Raman and ROA spectra were subtracted by asymmetric least squares smoothing method, and then smoothed with the ten-point Savitzky-Golay procedure using OriginPro software (OriginPro2018, OriginLab Corporation, Northampton, MA, USA).

UV-Vis and ECD spectra were recorded in the 220 to $700 \mathrm{~nm}$ spectral range using quartz cells with a path length of $10 \mathrm{~mm}$, a scanning speed of $100 \mathrm{~nm} / \mathrm{min}$, a bandwidth of $1 \mathrm{~nm}, 0.5 \mathrm{~s}$ response time, and an accumulation of a single scan on the Jasco J-815 spectrometer. The concentration of all 
samples was $0.1 \mathrm{mg} / \mathrm{mL}$. The baseline of the registered spectra was corrected using JASCO software (Jascow32, JASCO Corporation, Easton, MD, USA).

\section{Conclusions}

While it is not possible to distinguish between $(\mathrm{CN})_{2} \mathrm{Cbi}$ and $(\mathrm{CN})_{2} \mathrm{CbiP}$ by means of $\mathrm{RR}$, UV-Vis, or ECD spectroscopy, RROA turned out to be a sensitive probe for subtle structural alterations in the molecules measured in resonance with multiple electronic states. In the presented study, not only the RR spectra of two analogs, i.e., $(\mathrm{CN})_{2} \mathrm{Cbi}$ and $(\mathrm{CN})_{2} \mathrm{CbiP}$, were virtually the same, but also their UV-Vis and ECD spectra, which means that only the RROA method allows for successful distinction between these, only slightly structurally different, compounds. What is even more remarkable, the only structural difference between both molecules is the phosphate group located in the $f$-side chain, which is quite distant from the corrin ring, and obviously, that substitution should affect the corrin macrocycle conformation very slightly, but still enough to be detected on the respective RROA spectra. ROA spectroscopy is therefore highly sensitive to subtle alteration in a structure of truncated vitamins, but the ECD method still shows spectral changes accompanying axial ligands incorporation to the central cobalt ion, e.g., $(\mathrm{CN}) \mathrm{Cbl}$ vs. $(\mathrm{CN})\left(\mathrm{H}_{2} \mathrm{O}\right) \mathrm{Cby}(\mathrm{OMe})_{7}$. The current study is an important step in the dissemination of using resonantly enhanced ROA spectroscopy in studying the complex structure of corrinoids, which may prove crucial for a better understanding of their biological role.

Supplementary Materials: The following are available online, Figure S1: UV-Vis and ECD spectra of vitamin $\mathrm{B}_{12}$ and its truncated analogs measured before and after RROA experiments involving ROA laser exposure. All samples $(c=0.1 \mathrm{mg} / \mathrm{mL}$ ) were measured in cells with a path length of $1 \mathrm{~mm}$ and an accumulation of five scans; Table S1: Dissymmetry factor ( $g$-factor, ECD/UV-Vis) values, plotted for selected transitions, obtained from $(\mathrm{CN}) \mathrm{Cbl},(\mathrm{CN})_{2} \mathrm{Cbi},(\mathrm{CN})_{2} \mathrm{Cbi}-\mathrm{P}$, and $(\mathrm{CN})\left(\mathrm{H}_{2} \mathrm{O}\right) \mathrm{Cby}(\mathrm{OMe})_{7}$ experimental spectra; Table S2: CID (ROA/Raman) values, plotted for selected transitions, obtained from $(\mathrm{CN}) \mathrm{Cbl},(\mathrm{CN})_{2} \mathrm{Cbi},(\mathrm{CN})_{2} \mathrm{Cbi}-\mathrm{P}$, and $(\mathrm{CN})\left(\mathrm{H}_{2} \mathrm{O}\right) \mathrm{Cby}(\mathrm{OMe})_{7}$ experimental spectra.

Author Contributions: Conceptualization, M.B. and D.G.; methodology, E.M., A.J.W., and G.Z.; formal analysis, E.M., G.Z., M.H., and A.J.W.; investigation, E.M., G.Z., M.H., and A.J.W.; data curation, E.M.; writing-original draft preparation E.M., G.Z., M.H., and A.J.W.; writing-review and editing M.B. and D.G.; visualization E.M. and G.Z.; supervision, M.B. and D.G.; project administration, M.B.; funding acquisition, E.M. All authors have read and agreed to the published version of the manuscript.

Funding: This research was funded by the National Institute of Health, project No. R01 GM133184 and the National Center of Science (Poland), project PRELUDIUM-No. UMO-2019/33/N/ST4/01986.

Conflicts of Interest: The authors declare no conflict of interest.

\section{References}

1. Giedyk, M.; Jackowska, A.; Równicki, M.; Kolanowska, M.; Trylska, J.; Gryko, D. Vitamin B 12 transports modified RNA into E. coli and S. typhimurium cells. Chem. Commun. 2019, 55, 763-766. [CrossRef] [PubMed]

2. Clardy, S.M.; Allis, D.G.; Fairchild, T.J.; Doyle, R.P. Vitamin $B_{12}$ in drug delivery: Breaking through the barriers to a $\mathrm{B}_{12}$ bioconjugate pharmaceutical. Expert Opin. Drug Deliv. 2011, 8, 127-140. [CrossRef] [PubMed]

3. Braselmann, E.; Wierzba, A.J.; Polaski, J.T.; Chromiśnki, M.; Holmes, Z.E.; Hung, S.T.; Batan, D.; Wheeler, J.R.; Parker, R.; Jimenez, R.; et al. A multicolor riboswitch-based platform for imaging of RNA in live mammalian cells. Nat. Chem. Biol. 2018, 641, 343-372. [CrossRef]

4. Zelder, F.; Sonnay, M.; Prieto, L. Antivitamins for Medicinal Applications. ChemBioChem 2015, 16, $1264-1278$. [CrossRef]

5. Zhou, K.; Oetterli, R.M.; Brandl, H.; Lyatuu, F.E.; Buckel, W.; Zelder, F. Chemistry and Bioactivity of an Artificial Adenosylpeptide B 12 Cofactor. ChemBioChem 2012, 13, 2052-2055. [CrossRef]

6. Giedyk, M.; Goliszewska, K.; Gryko, D. Vitamin B 12 catalysed reactions. Chem. Soc. Rev. 2015, 44, 3391-3404. [CrossRef]

7. Ye, K.; Li, K.; Lu, Y.; Guo, Z.; Ni, N.; Liu, H.; Huang, Y.; Ji, H.; Wang, P. An overview of advanced methods for the characterization of oxygen vacancies in materials. Trends Anal. Chem. 2019, 116, 102-108. [CrossRef] 
8. Piao, Y.; Yamashita, M.; Kawaraichi, N.; Asegawa, R.; Ono, H.; Murooka, Y. Production of vitamin $\mathrm{B}_{12}$ in genetically engineered Propionibacterium freudenreichii. J. Biosci. Bioeng. 2004, 98, 167-173. [CrossRef]

9. Thibaut, D.; Blanche, F.; Cameron, B.; Crouzet, J.; Debussche, L.; Rémy, E.; Vuilhorgne, M. Vitamin B 12 Biosynthesis in Pseudomonas denitrificans. Vitam. B12 B12-Proteins 1998, 63-79. [CrossRef]

10. Kim, J.; Gherasim, C.; Banerjee, R. Decyanation of vitamin $\mathrm{B}_{12}$ by a trafficking chaperone. Proc. Natl. Acad. Sci. USA 2008, 105, 14551-14554. [CrossRef]

11. Gruber, K.; Puffer, B.; Kräutler, B. Vitamin $B_{12}$-derivatives-enzyme cofactors and ligands of proteins and nucleic acids. Chem. Soc. Rev. 2011, 40, 4346-4363. [PubMed]

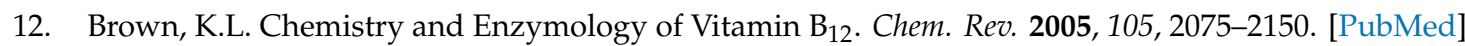

13. Marsh, E.N.G.; Drennan, C.L. Adenosylcobalamin-dependent isomerases: New insights into structure and mechanism. Curr. Opin. Chem. Biol. 2001, 5, 499-505.

14. Gerfen, G.J.; Licht, S.; Willems, J.P.; Hoffman, B.M.; Stubbe, J. Electron Paramagnetic Resonance Investigations of a Kinetically Competent Intermediate Formed in Ribonucleotide Reduction: Evidence for a Thiyl Radical-Cob(II)alamin Interaction. J. Am. Chem. Soc. 1996, 118, 8192-8197.

15. Bridwell-Rabb, J.; Drennan, C.L. Vitamin $\mathrm{B}_{12}$ in the spotlight again. Curr. Opin. Chem. Biol. 2017, 37, 63-70.

16. Proinsias, K.; Karczewski, M.; Zieleniewska, A.; Gryko, D. Microwave-Assisted Cobinamide Synthesis. J. Org. Chem. 2014, 79, 7752-7757.

17. Zou, X.; Evans, D.R.; Brown, K.L. Efficient and Convenient Method for Axial Nucleotide Removal from Vitamin $\mathrm{B}_{12}$ and Its Derivatives. Inorg. Chem. 1995, 34, 1634-1635.

18. Hassan, S.; Jackowska, A.; Gryko, D. Truncated vitamin $B_{12}$ derivative with the phosphate group retained. J. Porphyr. Phthalocyanines 2019, 23, 554-560.

19. Lee, J.; Mahon, S.B.; Mukai, D.; Burney, T.; Katebian, B.S.; Chan, A.; Bebarta, V.S.; Yoon, D.; Boss, G.R.; Brenner, M. The Vitamin $\mathrm{B}_{12}$ Analog Cobinamide Is an Effective Antidote for Oral Cyanide Poisoning. J. Med. Toxicol. 2016, 12, 370-379.

20. Dereven'kov, I.A.; Salnikov, D.S.; Makarov, S.V.; Surducan, M.; Silaghi-Dumitrescu, R.; Boss, G.R. Comparative study of reaction of cobalamin and cobinamide with thiocyanate. J. Inorg. Biochem. 2013, 125, 32-39.

21. Broderick, K.E.; Potluri, P.; Zhuang, S.; Scheffler, I.E.; Sharma, V.S.; Pilz, R.B.; Boss, G.R. Cyanide Detoxification by the Cobalamin Precursor Cobinamide. Exp. Biol. Med. 2006, 231, 641-649. [CrossRef] [PubMed]

22. Chowdhury, S.; Banerjee, R. Role of the Dimethylbenzimidazole Tail in the Reaction Catalyzed by Coenzyme $\mathrm{B}_{12}$-Dependent Methylmalonyl-CoA Mutase. Biochemistry 1999, 38, 15287-15294. [CrossRef] [PubMed]

23. Andruniow, T.; Jaworska, M.; Lodowski, P.; Zgierski, M.Z.; Dreos, R.; Randaccio, L.; Kozlowski, P.M. Time-dependent density functional theory study of cobalt corrinoids: Electronically excited states of methylcobalamin. J. Chem. Phys. 2008, 129, 85101. [CrossRef] [PubMed]

24. Reig, A.J.; Conrad, K.S.; Brunold, T.C. Combined Spectroscopic/Computational Studies of Vitamin $B_{12}$ Precursors: Geometric and Electronic Structures of Cobinamides. Inorg. Chem. 2012, 51, 2867-2879. [CrossRef]

25. Stich, T.A.; Buan, N.R.; Brunold, T.C. Spectroscopic and Computational Studies of $\mathrm{Co}^{2+}$ Corrinoids: Spectral and Electronic Properties of the Biologically Relevant Base-On and Base-Off Forms of $\mathrm{Co}^{2+}$ Cobalamin. J. Am. Chem. Soc. 2004, 126, 9735-9749. [CrossRef]

26. Stich, T.A.; Buan, N.R.; Escalante-Semerena, J.C.; Brunold, T.C. Spectroscopic and Computational Studies of the ATP:Corrinoid Adenosyltransferase (CobA) from Salmonella enterica: Insights into the Mechanism of Adenosylcobalamin Biosynthesis. J. Am. Chem. Soc. 2005, 127, 8710-8719.

27. Park, K.; Brunold, T.C. Combined Spectroscopic and Computational Analysis of the Vibrational Properties of Vitamin $\mathrm{B}_{12}$ in its $\mathrm{Co}^{3+}, \mathrm{Co}^{2+}$, and $\mathrm{Co}^{1+}$ Oxidation States. J. Phys. Chem. B 2013, 117, 5397-5410. [CrossRef]

28. Park, K.; Mera, P.E.; Escalante-Semerena, J.C.; Brunold, T.C. Resonance Raman spectroscopic study of the interaction between Co (II) rrinoids and the ATP:corrinoid adenosyltransferase PduO from Lactobacillus reuteri. J. Biol. Inorg. Chem. 2016, 21, 669-681. [CrossRef]

29. Dong, S.; Padmakumar, R.; Maiti, N.; Banerjee, R.; Spiro, T.G. Resonance Raman Spectra Show That Coenzyme $\mathrm{B}_{12}$ Binding to Methylmalonyl-Coenzyme A Mutase Changes the Corrin Ring Conformation but Leaves the Co-C Bond Essentially Unaffected. J. Am. Chem. Soc. 1998, 120, 9947-9948.

30. Puckett, J.M.; Mitchell, M.B.; Hirota, S.; Marzilli, L.G. Near-IR FT-Raman Spectroscopy of Methyl-B 12 and Other Cobalamins and of Imidazole and Imidazolate Methylcobinamide Derivatives in Aqueous Solution. Inorg. Chem 1996, 35, 4656-4662. 
31. Andruniow, T.; Zgierski, M.Z.; Kozlowski, P.M. Vibrational Analysis of Methylcobalamin. J. Phys. Chem. A 2002, 106, 1365-1373. [CrossRef]

32. Mayer, E.; Gardiner, D.J.; Hester, R.E. Resonance Raman spectra of vitamin $B_{12}$ and dicyanocobalamin. BBA Gen. Subj. 1973, 297, 568-570. [CrossRef]

33. Eschenmoser, A.J.; Scheffold, R.; Bertele, E.; Pesaro, M.; Gschwend, H. Synthetic corrin complexes. Proc. R. Soc. A 1965, 288, 306-323.

34. Kieninger, C.; Baker, J.A.; Podewitz, M.; Wurst, K.; Jockusch, S.; Lawrence, A.D.; Deery, E.; Gruber, K.; Liedl, K.R.; Warren, M.J.; et al. Zinc Substitution of Cobalt in Vitamin B 12 : Zincobyric acid and Zincobalamin as Luminescent Structural B 12 -Mimics. Angew. Chem. 2019, 58, 14568-14572.

35. Bonnett, R. The chemistry of the vitamin $\mathrm{B}_{12}$ group. Chem. Rev. 1963, 63, 573-605.

36. Bonnett, R.; Godfrey, J.M.; Math, V.B.; Scopes, P.M.; Thomas, R.N. Circular Dichroism of some Vitamin B 12 Derivatives. J. Chem. Soc. Perkin Trans. I 1973, 252-257. [CrossRef] [PubMed]

37. Firth, R.A.; Hill, H.A.O.; Pratt, J.M.; Williams, R.J.P.; Jackson, W.R. The Circular Dichroism and Absorption Spectra of Some Vitamin B 12 Derivatives. Biochemistry 1967, 6, 2178-2189.

38. Liptak, M.D.; Brunold, T.C. Spectroscopic and Computational Studies of $\mathrm{Co}^{1+}$ Cobalamin: Spectral and Electronic Properties of the "Superreduced" B 12 Cofactor. J. Am. Chem. Soc. 2006, 128, 9144-9156. [CrossRef]

39. Wagner, F. Reactions of the cyano and alkyl cobalamins. Proc. R. Soc. Lond. 1965, 288, 344-347.

40. Stich, T.A.; Brooks, A.J.; Buan, N.R.; Brunold, T.C. Spectroscopic and Computational Studies of $\mathrm{Co}^{3+}$-Corrinoids: Spectral and Electronic Properties of the $\mathrm{B}_{12}$ Cofactors and Biologically Relevant Precursors. J. Am. Chem. Soc. 2003, 125, 5897-5914. [CrossRef] [PubMed]

41. Machalska, E.; Zajac, G.; Gruca, A.; Zobi, F.; Baranska, M.; Kaczor, A. Resonance Raman Optical Activity Shows Unusual Structural Sensitivity for Systems in Resonance with Multiple Excited States: Vitamin $\mathrm{B}_{12}$ Case. J. Phys. Chem. Lett. 2020, 11, 5037-5043. [CrossRef]

42. Nafie, L.A. Theory of resonance Raman optical activity: The single electronic state limit. Chem. Phys. 1996, 205, 309-322. [CrossRef]

43. Merten, C.; Li, H.; Nafie, L.A. Simultaneous Resonance Raman Optical Activity Involving Two Electronic States. J. Phys. Chem. A 2012, 116, 7329-7336. [CrossRef] [PubMed]

44. Luber, S.; Neugebauer, J.; Reiher, M. Enhancement and de-enhancement effects in vibrational resonance Raman optical activity. J. Chem. Phys. 2010, 132. [CrossRef] [PubMed]

45. Zajac, G.; Kaczor, A.; Chruszcz-Lipska, K.; Dobrowolski, J.C.; Baranska, M. Bisignate resonance Raman optical activity: A pseudo breakdown of the single electronic state model of RROA? J. Raman Spectrosc. 2014, 45, 859-862. [CrossRef]

46. Zajac, G.; Kaczor, A.; Buda, S.; Młynarski, J.; Frelek, J.; Dobrowolski, J.C.; Baranska, M. Prediction of ROA and ECD Related to Conformational Changes of Astaxanthin Enantiomers. J. Phys. Chem. B 2015, 119, 12193-12201. [CrossRef]

47. Bogaerts, J.; Johannessen, C. On/off resonance Raman optical activity of human serum transferrin. J. Raman Spectrosc. 2019, 50, 641-646. [CrossRef]

48. Firth, R.A.; Hill, H.A.O.; Mann, B.E.; Pratt, J.M.; Thorp, R.G.; Williams, R.J.P. The chemistry of vitamin B 12 . Part IX. Evidence for five-co-ordinate cobalt (III) complexes. J. Chem. Soc. A 1968, 2419-2428. [CrossRef]

49. Day, P. A theory of the optical properties of vitamin $\mathrm{B}_{12}$ and its derivatives. Chim. Acta 1967, 7, 328-341. [CrossRef]

50. Perlman, D.; Toohey, J.I. Cobalt-free Corrinoids as Vitamin B 12 Antagonists. Nature 1966, $212,300-301$. [CrossRef]

51. Brunold, T.C. Combined spectroscopic/computational studies of metal centers in proteins and cofactors: Application to coenzyme $\mathrm{B}_{12}$. CHIMIA Int. J. Chem. 2004, 58, 186-193. [CrossRef]

Sample Availability: Samples of the compounds are not available from the authors. 